\title{
IN MEMORIAM PROFESSOR DANIEL GOEDHUIS (1905-1995)
}

Professor Daniel Goedhuis, born on January 31,1905 , in the city of Deventer (the Netherlands), peacefully died at his home, Ossington House, Ossington (Nottinghamshire, England) on October 5, 1995. In him, one of the world's first and finest experts in air and space law passed away, a man to whom the epithet of 'inspirator and originator' fully seems to apply and who, in time, will be recognized as part of legal history - a rare and enviable title few others can claim.

Goedhuis himself was most conscious of the privileged life that had been his, 'Looking back on my life', he wrote, 'the first thing I realize is how very lucky I have been and how very grateful I should be that fate or chance gave me the opportunity to participate in some ways in the revolutionary changes which resulted from the conquest of air and outer space' - a phrase taken from his memoirs as privately circulated. For well over nine decades, he also noted, he lived 'in a century in which greater and more fundamental changes in the world have occurred than in the last 1000 years', and he keenly felt the challenge they held to the lawyer faced with the need for new principles of world-structure and behaviour. Thus, almost from the beginning of air law, he took part in its development, whereas space law had his close interest from the very start of space technology.

Goedhuis took a Master's degree in law at Leyden University in 1928. Shortly afterwards, he was appointed Legal Adviser to the fledgeling KLM, a post be relinquished in 1931, when he became Secretary of IATA, then established in The Hague. In 1938, he found himself promoted to Secretary-General. After the war, he joined the Netherlands diplomatic corps as the Civil Air Attaché in London, Paris, Madrid, and Lisbon. His professional career doubled with an academic one. Having published a doctoral thesis on the 1929 Warsaw Convention and a treatise on national air legislation, both eminently practical works, he was in 1938 appointed a Lecturer in Air Law at Leyden and in 1947 a Professor, occupying a newly created chair, converted into the world's first Chair of Air and Space Law in 1961. This chair he held until reaching retirement age. Goedhuis published a Handbook on Air Law (in Dutch) in 1943 while in hiding as a reserve cavalry officer during the German occupation of the Netherlands. In that year, he successfully escaped from Dutch occupied territory, making his 
way to London via Portugal and Gibraltar. In London, Goedhuis soon became Secretary-General of a temporary IATA office.

Leaving aside his further activities in the field of air transport and air law, in particular when a Civil Air Attaché, mention should also be made here of the special bond Goedhuis had with the International Law Association, which he joined in 1938 on becoming a member of its Dutch Branch. It was in the ILA that he rose to prominence as an expert in space law. On October 4, 1957, the first Sputnik was launched. In 1956, anticipating events, the ILA already urged its Air Law Committee to study 'the problems connected with coming flights in the outer space and the legal nature of inter-planetary space' (Dubrovnik Conference Report, p. X). In 1958, as a member of that Committee, Goedhuis in a report he wrote proposed that the following principle be embodied in an ILA Resolution: 'The ILA is of opinion that outer space constitutes common property of mankind, open to use by all and not subject to appropriation by any one State' (New York Conference Report, p. 330). The ILA, not yet prepared to adopt such bold language, apparently preferred a milder formula for its Resolution on Air Sovereignty and the Legal Status of Outer Space (ibid., p. XII), but Goedhuis' principle eventually was included in the UN Treaty on Principles Governing the Activities of States in the Exploration and Use of Outer Space of January 27, 1967. The fact is illustrative of his leadership.

In 1960, the ILA came to establish a Committee on Space Law with Goedhuis as its Chairman. This is not the place to go into the details of his work as such, and I can merely indicate the subjects he dealt with in his many reports. They mainly come under two heads: the demarcation of air space and outer space, and the legal regime of outer space. Besides, Goedhuis had an open eye for the unprecedented ways of law-creation as practised under the pressure of a fastgrowing space technology. As to the legal regime of outer space, Goedhuis went into such aspects as the applicability to outer space of international law, including the UN Charter; outer space as the common property of mankind, already mentioned before; its peaceful uses; the appropriation of its resources; an international registration body for satellites; telecommunication by satellites, as well as broadcasting and remote sensing; the 1979 Moon Treaty; and the military uses of outer space. With regard to the technological aspects involved, he always provided proof of astonishing insight. For a résumé of much of Goedhuis' thought on space law, I may refer here to two major studies he contributed, one to The Present State of International Law under my Editorship (Kluwer, the Netherlands, 1973), pp. 201-244, the other to this Review under the title 'Reflections on Some of the Main Problems Arising in the Future Development of Space Law' (Vol. XXXVI, 1989, pp. 247-268), his swan song, in fact. 
The full measure of Goedhuis' significance as an air and space lawyer cannot, of course, be judged upon in these few lines, and a monography would seem to be in place, to be written when space law will have reached some form of completion. As yet, however, we may be sure that his role was a pioneering one, and that for all time to come he will have his place in the long line of eminent international lawyers to which his home country gave birth.

This Review is saddened by the departure of a good friend who in a period stretching from 1955 to 1989 had a total of eight articles published in it. ${ }^{1}$

To Professor Goedhuis' widow, his two sons and daughter, the Board expresses its deep-felt sympathy with the loss they have suffered.

Professor Maarten Bos The Hon. Editor-in-Chief

1. 'Het souvereiniteitsbegrip in het luchtrecht', 2 NILR (1955) pp. 225-242; 'Some Trends in the Political and Legal Thinking on the Conquest of Space', 9 NILR (1962) pp. 113-136; 'Reflections on the Evolution of Space Law', 13 NILR (1966) pp. 109-149; 'An Evaluation of the Leading Principles of the Treaty on Outer Space of 27th January 1967', 15 NILR (1968) pp. 17-41; 'Legal Aspects of the Utilization of Outer Space', 17 NILR (1970) pp. 25-50; 'Legal Implications of the Use of Direct Broadcasting and Remote Sensing Satellites and their Effect on International Relations', 23 NILR (1976) pp. 162-169; 'Conflicts on the Interpretation of the Leading Principles of the Moon Treaty of 5 December 1979', 28 NILR (1981) pp. 14-29; 'Reflections on Some of the Main Problems Arising in the Future Development of Space Law', 36 NILR (1989) pp. 247-268. 